Vol. 7 (1998): 207-217.

\title{
The key elements for genetic response in Finnish dairy cattle breeding
}

\author{
Jarmo Juga and Ulla Voutilainen
}

The Finnish Animal Breeding Association, PO Box 40, FIN-01301 Vantaa, Finland, e-mail: jarmo.juga@mloy.fi

\begin{abstract}
This paper reviews some key elements of Finnish animal breeding research contributing to the Finnish dairy cattle breeding programme and discusses the possibilities and problems in collecting data for genetic evaluation, prediction of breeding values both within and across countries, estimation of the economic value of important traits, and selection of bulls and cows. Economic values are calculated for fertility, udder health and production traits when one genetic standard deviation unit (gen. sd.) is changed in each trait independently and the financial returns from selection response in the Finnish dairy cattle breeding programme are estimated.

The following components were used to calculate the economic value of mastitis treatments: 1) cost of mastitis including discarded milk and treatment costs, 2) reduction in milk price due to higher somatic cell count, 3) replacement costs and 4) lower production level of the herd due to involuntary culling of cows because of udder problems. A high somatic cell count lowers the price of milk and eventually leads to involuntary culling. For treatments for fertility disorders the following costs were included: 1) treatment costs 2) higher replacement costs and 3) decreased milk production in the herd. Days open included the following costs: 1) extra insemination, 2) reduced annual milk yield and 3) fewer calves born.

Animal breeding was found to be a very cost effective investment, yielding returns of FIM 876.9 per cow from one round of selection when the gene flow was followed for over 25 years in the Finnish dairy cattle breeding programme.
\end{abstract}

Key words: breeding goal, breeding programme, dairy cattle, financial returns, multiple trait selection

\section{Introduction}

The aim of the national breeding programme is to improve the cost-effectiveness of milk production by genetic progress in economically important traits. The Finnish dairy cattle breeding programme has been successful in improving production traits and simultaneously achieving a favourable, or at least not unfavourable, genetic change in many functional traits, e.g. udder health, milkability and conformation (Kor- 


\section{Seminar in honour of the 100th anniversary of MTT}

honen and Juga 1996). The only trait that has clearly declined is female fertility, in which the number of days open has increased.

A successful breeding programme has to consider many aspects, namely, definition of the breeding goal, recording schemes, prediction of breeding values (BV), selection of animals and mating strategies. We here review the key results of Finnish animal breeding research that have contributed to Finlands dairy cattle breeding programme and discuss the possibilities and problems in collecting data for genetic evaluation, prediction of breeding values both within and across countries, and selection of parental animals. We also estimate the economic value of traits affecting the profitability of dairy production and attempt to estimate the financial returns yielded by one round of selection of bulls and cows.

\section{Recording performance}

The base for accurate genetic evaluation is reliable data on the performance and pedigrees of animals, and on the environmental effects influencing their performance. All traits with a clear impact on the economics of dairy production, animal welfare or environmental load need to be recorded using common terms and measures and they should be recorded when there is sufficient variation among them. Many continuously recorded traits such as milk production or growth of the animal have convenient scales, e.g. kg. For traits which do not have a convenient scale and for which a scoring system is used, e.g. linear type scoring and calving ease, standard scores and recording procedures are required. It is important that all countries should use the same standards in recording, which is why the International Committee of Animal Recording (ICAR) has such an important role in setting standards.

To be able to compare the results from recording and genetic evaluation within and across countries we need some standardisation. For data to be useful to a genetic evaluation process, they must meet certain requirements. The main requirements are (Tier and Graser 1994):

- information must be available on how the animal has been treated in comparison with contemporary herd mates;

- the data forming the basis of selection are included in multiple trait analysis;

- data are contrasted with many others, i.e. data are on large groups with descendants from a variety of parents;

- the animals and their relatives can be reliably identified throughout their lives - both in the field and in the data system; and

- information is available on systematic effects, such as age, when observed, the age of the dam, the breed and sex of the animal.

According to van Arendonk et al. (1998), $15 \%$ of the errors in pedigree registration in a nucleus scheme cause a substantial reduction in genetic progress. Such a high rate of errors is not acceptable in well organised nucleus schemes, the rate of pedigree errors before DNA verification of possible bull dams in Finland being, for instance only 1 to $2 \%$. However, the example illustrates well the importance of the quality of the data.

All the Nordic countries, Finland included, have a long history of also recording secondary traits such as fertility, health, temperament, milkability, stillbirths, calving ease and conformation. A new set of data to be used in performance evaluation is the data originating from slaughter houses. Such data will be available through the new identification system required by the EU, according to which all animals have to be uniquely identified and traced back to herds of origin, and the data must be stored in a central database. The slaughter information can easily be linked to recording information via the unique identity number and used in genetic evaluation of slaughter weight and carcass classification and fat scores.

Research into the utilisation of slaughter information in genetic evaluation of pure bred 


\section{AGRICULTURAL AND FOOD SCIENCE IN FINLAND}

Vol. 7 (1998): 207-217.

dairy cattle and the beef sires used in crossbreeding with dairy cows is currently under way in Finland. Preliminary results from the first data set of the performance of different breeds in crossbreeding are already available, and some (co)variance components have been estimated. The goal is to have BLUP (Best Linear Unbiased Prediction) indices for the slaughter weight and carcass and fat scores before long for all breeds in Finland and to include them in the total merit index of dairy bulls (Liinamo and van Arendonk 1998).

ICAR will be facing new challenges in standardisation in the near future, since members require more flexibility in recording schemes due to advances in the electronic devices connected to milking machines and feeding robots and due to the increasing interest in self-recording on farms. Improvements in electronic measuring generate huge amounts of daily data that will replace specific test days in milk recording and enable the daily on farm recording of new traits such as feed efficiency and somatic cell count.

\section{Prediction of breeding values}

Genetic evaluation is of fundamental value in animal breeding, since the selection of animals is most accurately carried out by using the predicted breeding values or expected progeny differences (EPD) of traits in the breeding goal. Due to its important role, the methodology has been studied intensively during the recent decades with very good results. Good predictions depend upon high-quality data, appropriate models and good estimates of (co)variances. The predictions should be made using all available qualified data and allow valid comparison of animals across space and time (Tier and Graser 1994). Collecting the data is a huge and a very costly task. Hence, it is important that the recording should be carried out efficiently, concentrating on economically valuable traits and utilising, whenev- er possible, information coming from other sources, too. Due to these costs the number of traits evaluated in most countries is usually very limited; the emphasis is on milk production traits, and functional traits such as fertility, calving difficulties and health, tend to be neglected. The cost is not the only reason for failing to record secondary traits, however; it is very often due to the lack of a nationally uniform infrastructure, competition between local companies and organisations, poor logistics and historical load.

Production systems vary considerably between countries and continents. The models used in genetic evaluation should therefore be optimised in such a manner that the information collected accounts for heterogeneous variance, heterosis and genotype-by-environment interaction. This means that a model which is good in one country is not necessarily so in another.

Good-quality data have been used intensively to study evaluation methods in Finland. During the last 20 years much research has been carried out on BLUP methods, which are now the most widely used procedures for predicting breeding values in livestock. The thrust of research has been on estimating the (co)variance components of milk production traits (Mäntysaari and Van Vleck 1989, Juga 1992, Pösö and Mäntysaari 1996a, b) and developing evaluation procedures for production traits, replacing the sire-model (Syväjärvi et al. 1983) with the animal model (AM) (Strandén and Mäntysaari 1992). The latter was taken into routine use in Finland as one of the first countries in the world, in 1990. After implementation of the AM in practice the statistical model has been studied carefully to reduce the bias originating from preferential treatment of bull dams (Uimari and Mäntysaari 1995, Lidauer and Mäntysaari 1996).

More recently, the emphasis has been on testday models using random regressions to predict breeding values for production traits of dairy animals (Kettunen et al. 1997), that will permit better modelling of contemporary groups across test days and prediction of breeding values for lactation curves. Another advantage of test-day 


\section{AGRICULTURAL AND FOOD SCIENCE IN FINLAND}

\section{Seminar in honour of the 100th anniversary of MTT}

models is that the solutions of herd, test-day and animal effects can be utilised in management reports and follow-ups of feeding practices.

Other traits have not been neglected, either. The genetic parameters of fertility traits (Mäntysaari and Van Vleck 1989, Pösö and Mäntysaari 1996b, Hyppänen and Juga 1997), health traits (Pösö and Mäntysaari 1996a, Luttinen and Juga 1997), conformation traits (Korhonen and Hassila 1995) and calving traits (Niskanen and Juga 1997) have all been analysed and used in national evaluation procedures. Predicting the breeding values of functional traits forms the base for so called "Nordic profile" (Juga 1998), since selection for total merit requires information on all economically important traits.

\section{Properties of the animal model predictors}

The prediction method currently most widely used is the BLUP method with the AM (Henderson 1984). It uses all available information (on performance, pedigree, related traits, systematic (fixed) effects) simultaneously for providing an accurate and unbiased prediction of an animal's BV. Every phenotypic observation on an animal is determined by environmental and genetic effects. It is usually assumed that phenotypic observations and genetic and residual effects follow a multivariate normal distribution, implying that traits are determined by infinitely many additive genes of infinitesimal effect at unlinked loci, what is known as the infinitesimal model (e.g. Bulmer 1980), although Strandén and Gianola (1997) found some advantages in using t-distributed residuals over Gaussian distributed residuals. It is also assumed that genetic and residual variances are known or, at least, that their proportionality is known, and that there is no correlation between the genetic and residual effects (Henderson 1984).
The genetic effects include additive genetic effects, dominance and epistasis. Since the additive genetic value is a function of the genes transmitted from parents to progeny, it is the main component for selection and therefore the main component of interest. Use of more complicated genetic models has also been studied, for instance by including the dominance effect in the model (Smith and Mäki-Tanila 1990, Uimari and Kennedy 1990, Uimari and Mäki-Tanila 1992). Including dominance effects in the model increases the computational problems, which is why they are usually ignored.

Use of AM predictors increases the correlation between the breeding values estimated, which is an unfavourable property of the model since it leads to increasing annual rates of inbreeding. Research has therefore put more effort into optimising the breeding programmes to find an appropriate balance between expected genetic gain and expected decline in fitness (Meuwissen and Woolliams 1994).

Full use of the AM requires that sound genetic parameters should be available, especially when direct-maternal and/or multi-trait models requiring the genetic correlations $\left(\mathrm{R}_{\mathrm{g}}\right)$ between effects and/or traits to have been estimated reliably are used. Choosing an optimal model is important for forming groups of contemporaries, which is a special problem in Finland with its small herd sizes, studying genotype-by environment interactions, and building genetic groups when selection paths are differentiated (Ménissier 1994). Improving the models and methods is important, since the accuracy of predicted breeding values contributes directly to genetic response (e.g. Falconer and Mackay 1996). Such improvement is feasible due to the increasing power and decreasing costs of computers and to the greater efficiency of computing algorithms. Efforts to improve the prediction methods require some investment, but the increased genetic response affects the whole population and thus makes the investment very profitable. 


\section{AGRICULTURAL AND FOOD SCIENCE IN FINLAND}

Vol. 7 (1998): 207-217.

\section{International genetic evaluation}

In many European countries dairy cattle breeding has relied on the import of superior sires from other populations, mainly Holstein breed from the USA. The difficulty is to identify the foreign sires with the greatest potential for making a genetic contribution to a local population. Not only do methods of evaluation differ between countries, but results are expressed in widely differing ways, different bases are used and there are genotype-by-environment interactions (Wickham et al. 1996). Furthermore, breeding objectives differ between countries due to different production systems.

Due to the increasing international trade in genetic material and joint breeding programmes including progeny testing of bulls across countries by major artificial insemination companies it has become important to be able to compare breeding animals between countries. To do this two approaches have recently been used: 1) the calculation of international indices from national evaluation results using Schaeffer's $(1985,1994)$ methods for multiple country comparison as is done with dairy bulls by INTERBULL (Banos et al. 1994); 2) the calculation of across country evaluations simultaneously starting with data such as those in the North American Cattle Evaluation (NACE) for Hereford cattle in USA and Canada (Bertrand et al. 1997). The problems in optimising the statistical model increase, however, when one goes over to multiple country evaluation. This is due to differences in production systems and to poor genetic links between countries. With weak genetic links between two populations the genetic correlation will be underestimated (Sigurdsson and Banos 1995); if no links exist between the populations, across-country comparison is not possible.

The across-country comparison of dairy bulls is carried out by INTERBULL using the multiple-country comparison method (MACE) described by Schaeffer (1994), which allows for less than unity genetic correlations between countries. Currently 20 countries send in evaluation data on production traits for Holstein-Friesian, eight countries for Ayrshire, ten countries for Brown Swiss, four countries for Guernsey, six countries for Jersey and six countries for Simmental breed (Interbulletin 1997). More than 50000 Holstein-Friesian bulls, 11000 Simmental bulls and fewer than 10000 bulls per breed from other breeds across countries get an international evaluation, which is published for each participating country on their own base and scale. The breeding organisations in each country subscribing to the INTERBULL service are responsible for publishing the results; no other body or country is allowed to do so.

Future research priorities in INTERBULL will reflect the greater number of traits being considered for international evaluations. Priority will be given to research seeking to solve the practical problems associated with making accurate international comparisons of dairy animals (Wickham et al. 1996).

Integrated breeding value calculations based on raw data from more than one country are a topic of study for production and functional traits, at least within Nordic countries. The integrated breeding value estimation can be seen as a final goal in across-country genetic evaluation, since genetic correlations can be estimated from original data and he evaluation is carried out with the same method in both countries. Problems may be caused, however, by the very large data sets, differences in trait definitions and recording precision, difficulties in identifying animals between countries, and poorly linked data, preventing genetic parameters to be estimated between countries and traits.

\section{Defining the breeding goal}

Breeders are faced with the question of combining information on different traits of interest before animals are ranked. Constructing a total merit index from $\mathrm{BV}$ s provided by an AM using 


\section{Seminar in honour of the 100th anniversary of MTT}

the classical selection index theory (Hazel 1943) is no trivial task. It requires information on the economic value of individual traits in the breeding goal and on the covariance structure within the goal traits and between the goal traits and information traits. It is very often difficult to quantify the true economic value of a trait, as it is to estimate positive definite covariance matrices between many different traits simultaneously, particularly with the limitations imposed by computer resources. Groen et al. (1997) gave a detailed review of the methods used in defining the breeding goal, calculating the economic weights and constructing the total merit index. The breeding goal can be written as

$\mathbf{H}_{\mathrm{kl}}=\mathbf{a}_{\mathrm{kl}}{ }^{\prime} \mathbf{g}$, where $\mathbf{a}_{\mathrm{kl}}=\mathbf{c}_{\mathrm{l}} \mathbf{v}$

and $\mathbf{H}_{\mathrm{kl}}$ is the aggregate genotype of an animal, $\mathrm{k}$ is the time for comparison, 1 is the selection path, $\mathbf{a}_{\mathrm{kl}}$ is a m*1 vector of discounted economic values of $\mathrm{m}$ genotype traits, $\mathbf{g}$ is a $\mathrm{m} * 1$ vector of genetic superiority of $m$ genotype traits, $\mathbf{c}_{1}$ is a $\mathrm{m}^{*} \mathrm{~m}$ diagonal matrix with cumulative discounted expressions of $\mathrm{m}$ genotype traits, and $\mathbf{v}_{\mathrm{k}}$ is a $\mathrm{m}^{*} 1$ vector with economic values of $\mathrm{m}$ genotype traits.

The aggregate genotype cannot be observed, since the genotypic values of the traits in aggregate $\mathrm{BV}$ are not measurable. The practical solution is to predict the aggregate genotype with a selection index method (Hazel 1943). The information does not necessarily need to be on the same traits included in the aggregate genotype (total merit); some correlated traits can also be used. A selection index can generally be presented as (Groen et al. 1996)

$\mathbf{I}_{\mathrm{kl}}=\mathbf{b}_{\mathrm{kl}} \mathbf{x}^{\prime}$, where $\mathbf{b}_{\mathrm{kl}}=\mathbf{P}^{-1} \mathbf{G} \mathbf{a}_{\mathrm{k} 1}$

and $\mathbf{b}_{k 1}$ is a $n^{*} 1$ vector with regression coefficients of $\mathrm{n}$ index traits, $\mathbf{x}$ is a $\mathrm{n}^{*} 1$ vector with observations, $\mathbf{P}$ is a $n * n$ matrix with covariances between index traits and $\mathbf{G}$ is a $\mathrm{m}^{*} \mathrm{n}$ matrix with covariances between $m$ genotype traits and $\mathrm{n}$ index traits.

No universally best method exists for deriving economic values; what is best will depend on the traits and production circumstances considered and on what is possible in practice (Groen et al. 1997). Groen (1989) lists five criteria to be considered when deriving economic weights:

1. Efficiency: biological versus economic definition

2. Perspective: to maximise profit (=revenuescosts), to minimise costs or to maximise revenues/costs

3. Planning term: strategic versus tactical

4. System level: animal, farm, sector or international

5. Method: positive approach (data evaluation) versus normative approach (data simulation)

All five aspects provide alternative strategies that can be justified. Therefore no universally acceptable economic values exist; these values need to be derived in each country.

The economic values for production, health and fertility traits were calculated at both animal and herd level using the information from Finnish milk recording and progeny testing of dairy bulls. Milk recording data from Finland in 1995 were used to estimate the average feeding cost of maintenance and production. All product prices and production levels were from autumn 1996, and genetic standard deviations were from the national genetic evaluation of dairy cattle carried out in December 1996. Finland has a national quota for total milk (carrier + fat + protein) or total fat within the EU and, as a result, farm quotas are used. Derivation of economic values at herd level, i.e. rescaling (Smith et al. 1986), is therefore logical and has to be used when index weights are calculated for national use. At animal level the revenues from increased output are maximised, but by rescaling we minimise the cost per unit of output. This yields lower economic values for production traits (Table 1) and hence a higher relative value for functional traits. Finland has not exceeded the country quota since joining the EU, which means that farm quotas have not been realised either. It therefore makes sense to use the animal level for herds that are ready to take greater risks. Hence 
Vol. 7 (1998): 207-217.

the breeding objectives will differ somewhat between herds. Breeding objectives will also differ due to the preferences of farmers and production circumstances. This has been made possible, and actually encouraged to some extent, by the breeding planning services provided by extension organisation. However, inseminations by elite bulls, young bulls and beef bulls across herds follow, on average, the national recommendations, which are $50-55 \%, 40-45 \%$ and $5-10 \%$, respectively.

The following components were included in calculating the economic value of mastitis treatments: 1) cost of mastitis including discarded milk and treatment costs, 2) reduction in milk price due to the higher somatic cell count, 3 ) replacement costs and 4) the lower production level of the herd due to involuntary culling of cows because of udder problems. A high somatic cell count lowers the price of milk and eventually leads to involuntary culling. For treatments for fertility disorders the following costs were included: 1) treatment costs, 2) higher replacement cost and 3) decreased milk production in the herd. Days open included the following costs: 1) extra insemination, 2) reduced annual milk yield and 3) lower number of calves born. The economic values for different traits per genetic standard deviation at animal and herd level are presented in Table 1. The economic values correspond quite well to the current index weights used in the total merit index. The economic value of protein yield is approximately twice the economic value of udder health or daughter fertility traits.

\section{Genetic response in a large dairy cattle breeding scheme}

The most widely used selection scheme in dairy cattle breeding is based on progeny testing and selection of bulls to be used in artificial insemination (AI). The schemes in different countries
Table 1. The economic value of a change in the genetic standard deviation unit ( 10 index points in relative indices) in different traits in Finnish Ayrshire.

\begin{tabular}{lcc}
\hline Trait & $\begin{array}{l}\text { Economic value per } \\
\text { genetic s.d., cow level } \\
\text { (FIM) }\end{array}$ & $\begin{array}{l}\text { Economic value per } \\
\text { genetic s.d., rescaling } \\
\text { for milk traits (FIM) }\end{array}$ \\
\hline Fat yield & 127 & 73 \\
Protein yield & 366 & 259 \\
Carrier & 253 & 144 \\
Fertility treatments & 71 & 71 \\
Days open & 80 & 80 \\
Mastitis treatments & 96 & 96 \\
Somatic cell count & 33 & 33 \\
Growth rate ${ }^{1}$ & 104 & 104 \\
\hline
\end{tabular}

' from Liinamo and van Arendonk 1998.

more or less follow the optimisation strategy introduced by Skjervold (1963), with some variation in current applications. Interest in using multiple ovulation and embryo transfer in nucleus breeding (MOET) has increased since the early 1980 s, when the method was introduced by Nicholas and Smith (1983). Many studies of alternative MOET schemes were published after Juga and Mäki-Tanila (1987) published their results showing that the original results obtained by Nicholas and Smith (1983) were too optimistic. New strategies concentrated mainly on alternative mating designs (e.g. Ruane and Thompson 1991, Strandén et al. 1991, Woolliams 1989) or on maximising the genetic gain while constraining the increase in inbreeding rate (Meuwissen 1997). No country has based its dairy cattle breeding solely on a MOET scheme, but many nucleus breeding programmes have been set up to accomplish AI-breeding schemes, here in Finland too, where we have moved from a decentralised scheme (Mäntysaari et al. 1996) to an open centralised nucleus scheme. Nucleus breeding schemes are expected to increase the genetic response in a breeding scheme by better controlled management of animal selection, a shorter generation interval and future prospects of including marker assisted selection (MAS) or other biotechnological methods in the pro- 
Seminar in honour of the 100th anniversary of MTT

Table 2. The discounted genetic response in different paths in the Finnish dairy cattle breeding programme (adapted from Korhonen and Juga 1996) and the financial returns of genetic response.

\begin{tabular}{|c|c|c|c|c|c|c|}
\hline & Bull sires & Bull dams & Cow sires & Cow dams & $\begin{array}{l}\text { Total genetic } \\
\text { response }\end{array}$ & $\begin{array}{l}\text { Financial } \\
\text { returns FIM }\end{array}$ \\
\hline $\begin{array}{l}\text { Discounted expression } \\
\text { Milk yield }\end{array}$ & 0.283 & 0.407 & 0.808 & 0.907 & & \\
\hline (carrier) & 97.8 & 265.6 & 303.3 & -11.8 & 654.9 & 269.2 \\
\hline Protein yield & 3.8 & 8.6 & 11.6 & 0.5 & 24.5 & 663.8 \\
\hline Days open & 0.9 & 1.2 & 0.7 & -0.18 & 2.6 & -56.1 \\
\hline Total & & & & & & 876.90 \\
\hline
\end{tabular}

gramme. Nucleus breeding may, however, impair the effective population size and the accuracy of selection when $G^{*} E$ interaction would exist. Hence the strategy of maximising the genetic response with a predefined rate of inbreeding (Meuwissen 1997) would be a logical choice in effective but sustainable nucleus breeding.

A well-managed breeding programme generates substantial returns from each year's genetic response. The returns therefore accumulate over years, making animal breeding a very good investment. According to Hill (1974) the discounted economic response from a single selection round at time $\mathrm{tx}_{(\mathrm{t})}$ can be expressed as

$\mathrm{x}_{(t)}=\mathrm{c}^{t} \mathbf{w}^{\prime} \mathbf{r}_{(t)}$

where $c^{t}$ is the discount factor, $\mathbf{w}^{\prime}$ is the vector of undiscounted returns over selection paths and traits and $\mathbf{r}_{(t)}$ is the selection differential.

Using the realised selection differentials given by Korhonen and Juga (1996) and following the respective discounted expressions with a $3 \%$ interest rate for a 25 year period for bull sire, cow sire, bull dam and cow dam paths (Table 2) and multiplying the discounted selection differentials by the rescaled economic values from Table 1, we achieved an economic response of FIM 876.9 per cow. Negative weight for fat content has been excluded from the total merit index since 1996 and no negative trend is expected, which is why the change in fat traits was not included in this calculation. A horizon of 25 years reflects slightly more than three genera- tions with 7.6 years of average generation interval (Korhonen and Juga 1996), which is long enough to be equal to the asymptotic rate of response in a continuing programme (Hill 1974). The long perspective causes some problems, too, since the method uses implicit assumptions of the same economic values and similar selection within selection paths over the years.

The response is accumulated over successive selection rounds, which is typical only of animal breeding investments. Note that when the economic genetic response is cumulative, the costs are not, hence a profit could still be made even if the yearly costs were greater than the returns from the yearly gain. However, with relatively low discount rates, as today, when the real interest rate is low, the profit horizon can have a major effect on the expected total gain (Weller 1994). Increasing the discount rate to 5\% would have approximately the same effect as reducing the time horizon to 20 years.

\section{Concluding remarks}

Genetic evaluation is a powerful tool for the selection of animals. The animal model BLUP is now a method of choice for calculating breeding values with high accuracy. Increased computing power permits the use of complicated multiple trait models including direct and ma- 
Vol. 7 (1998): 207-217.

ternal effects in dairy cow evaluation. The method requires the estimation of reliable genetic parameters, which is a challenging task. A new era in dairy cattle genetic evaluation is the across country comparison, which gives more accuracy to the import and export of superior semen, embryos and live animals and to joint breeding programmes between countries.

The importance of functional traits such as udder health and daughter fertility is clearly demonstrated in economic values. The costs included in the calculation were direct costs; animal welfare or other ethical aspects were not emphasised. Including these factors would inevitably increase the economic value of such traits. Hence more emphasis should be placed globally on evaluating traits other than production ones and on calculating a total merit index giving the maximum response in the total economic value of milk and meat production. Total merit indices, which put the breeding goal into effect in each country, should really reflect the local economic and environmental circumstances to allow variations for selection practices between countries. This would maintain the genetic variation in the global breeding population and enable alternative genetics to be imported from other subpopulations when the population size of a country is limited.

Animal breeding was found to be a very costeffective investment, resulting in returns of FIM 876.9 per cow from each round of selection when the gene flow was followed for over 25 years in Finnish dairy cattle breeding programme. And yet the predicted genetic response in this programme is only moderate, leaving much room for improvement in all parts of the programme. Future advances in prediction methods, nucleus schemes and international co-operation will doubtless improve the returns for the benefit of dairy farmers.

\section{References}

Banos, G., Philipsson, J., Gundel, M., Juga, J. \& Sander-Nielsen, U. 1994. Linear model comparison of black-and-white dairy bulls from the Nordic countries. Acta Agriculturae Scandinavica, Section A, Animal Science 44: 129-137.

Bertrand, K., Little, D., Nelson, A. \& Benyshek, L. 1997. North American Hereford cattle evaluation. In: 1997 Sire Summary. Canadian Hereford Association. p. 34.

Bulmer, M. G. 1980. The mathematical theory of quantitative genetics. Calendor Press, Oxford, UK.

Falconer, D.S. \& Mackay, T.F.C. 1996. Introduction to quantitative genetics. IV edition. Longman, Longman House, Burnt Mill, Harlow, Essex CM20 2JE, England.

Groen, A.F. 1989. Cattle breeding goals and production circumstances. PhD Thesis, Dept. of Animal Breeding, Wageningen Institute of Animal Sciences.

- , Steine, T., Colleau, J., Pedersen, J., Pribyl, J. \& Reinsch, N. 1997. Economic values in dairy cattle breeding, with special reference to functional traits. Livestock Production Science 49: 1-21.

Hazel, L.N. 1943. The genetic basis for constructing selection indexes. Genetics 28: 476-490.

Henderson, C.R. 1984. Applications of linear models in animal breeding. University of Guelph Press, Guelph, Canada.

Hill, W.G. 1974. Prediction and evaluation of response to selection with overlapping generations. Animal Production 18: 117-139.

Hyppänen, K. \& Juga, J. 1997. Environmental and genetic effects on the 60-day non-return rate in Finnish Al bulls. International workshop on genetic improvement of functional traits in cattle: Fertility and reproduction, Grub, Germany, 23-25 November 1997. (in press).

Interbulletin 1997. August 1997 evaluation summary. INTERBULL Centre, Uppsala, Sweden. 4 p.

Juga, J. 1992. Estimation of variances and covariances of milk traits by REML with an individual animal model. Acta Agriculturae Scandinavica, Section A, Animal Science 42: 198-204.

- 1998. The Nordic model for animal welfare and sustainability, Is it competitive? Acta Agriculturae Scandinavica, Section A, Animal Science, Suppl. (in press).

- \& Mäki-Tanila, A. 1987. Genetic change in a nucleus breeding dairy herd using embryo transfer. Acta Agriculturae Scandinavica 37: 511-519.

Kettunen, A., Mäntysaari, E.A. \& Strandén, I. 1997. Anal- 


\title{
AGRICULTURAL AND FOOD SCIENCE IN FINLAND
}

\author{
Seminar in honour of the 100th anniversary of MTT
}

ysis of first lactation test day milk yields by random regression model. Proceedings of the INTERBULL annual meeting, 28-29 August 1997, Wienna, Austria. Interbull Bulletin No. 16: 39-41.

Korhonen, T. \& Hassila, M. 1995. BLUP-raksuja. Nauta 3: 7-9.

- \& Juga, J. 1996. Realized selection response in Finnish Ayrshire population. Proceedings of the. 47th Annual meeting of the EAAP, Lillehammer, Norway, 26-29 August 1996. p. 192.

Lidauer, M. \& Mäntysaari, E. 1996 Detection of bias in animal model pedigree indices of heifers. Agricultural and Food Science in Finland 5: 387-397.

Liinamo A.-E. \& van Arendonk, J.A.M. 1998. Combining selection for carcass quality and milk traits in dairy cattle. Proceedings of the 6th World Congress on Genetics Applied to Livestock Production, 11-16 January 1998, Armidale, Australia. Vol. 25: 387-390.

Luttinen, P. \& Juga, J. 1997. Genetic relationships between milk yield, somatic cell count, mastitis, milkability and leakage in Finnish dairy cattle population. Proceedings of the International Workshop on Genetic Improvement of Functional Traits in Cattle; Health. Uppsala, Sweden, June 1997. Interbull Bulletin No 15: 78-83.

Mäntysaari, E. \& Van Vleck, L.D. 1989. Estimation of genetic parameters for production and reproduction in Finnish Ayrshire cattle. Journal of Dairy Science 72: 2375-2386.

- , Thuneberg-Selonen, T., Hyppänen, K. \& Juga, J, 1996. Finnish embryo transfer breeding program "ASMO": description of the goals and a summary of the results of initial selection. Agricultural and Food Science in Finland 5: 491-501.

Ménissier, F. 1994. Genetic evaluation and improvement of beef cattle: Overview and introductive commentary. Proceedings of the 5th World Congress on Genetics Applied to Livestock Production, 7-12 August 1994, Guelph, Canada, Vol. 17: 151-152.

Meuwissen, T.H.E. 1997. Maximizing the response of selection with a predefined rate of inbreeding. Journal of Animal Science 75: 934-940.

- \& Woolliams, J. 1994. Effective sizes of livestock populations to prevent a decline in fitness. Theoretical and Applied Genetics 89: 1019-1026.

Niskanen, S. \& Juga, J. 1997. Calving difficulties and calf mortality in Finnish dairy cattle population. Proceedings of the International workshop on genetic improvement of functional traits in cattle: Fertility and reproduction, Grub, Germany, 23-25 November 1997. (in press).

Nicholas, F.W. \& Smith, C. 1983. Increased rates of genetic change in dairy cattle by embryo transfer and splitting. Animal Production 36: 341-353.

Pősō, J. \& Măntysaari, E.A. 1996a. Relationships between clinical mastitis, somatic cell score and production for the first three lactations of Finnish Ayrshire. Journal of Dairy Science 79: 1284-1291.

- \& Mäntysaari, E.A. 1996b. Genetic relationships between reproductive disorders, operational days open and milk yield. Livestock Production Science 79: 4148.
Ruane, J. \& Thompson, R. 1991. Comparison of simulated and theoretical results in adult MOET nucleus schemes for dairy cattle. Livestock Production Science 28: 1-20.

Schaeffer, L.R. 1985. Model for international evaluation of dairy sires. Livestock Production Science 12: 105115.

- 1994. Multiple-country comparison of dairy sires. Journal of Dairy Science 77: 2671-2678.

Sigurdsson, Á., Banos, B. \& Philipsson, J. 1995. Estimation of international (co)variance components. In: Sigurdsson, Á. (ed.). Multiple trait genetic evaluation of dairy cattle within and across country. Dissertation, Swedish University of Agricultural Sciences, Depatment of Animal Breeding and Genetics, Publication No. 120, Uppsala, Sweden.

Skjervold, H. 1963. The optimum size of progeny groups and optimum use of young bulls in Al breeding. Acta Agriculturae Scandinavica 13: 131-140.

Smith, C., James, J.W. \& Brascamp, E.W. 1986. On the derivation of economic weights in livestock production. Animal Production 43: 545-551.

Smith, S.P. \& Mäki-Tanila, A. 1990. Genotypic covariance matrices and their inverces for models allowing dominance and inbreeding. Genetic Selection and EvoIution 22: 65-91.

Strandén, I. \& Gianola, D. 1997. Gaussian versus t mixed effects linear models for milk yield in Ayrshire cattle. Proceedings of the 48th Annual Meeting of the EAAP, 25-28 August 1997, Wienna, Austria. p. 55.

- , Măki-Tanila, A. \& Mäntysaari, E. 1991. Genetic progress and rate of inbreeding in a closed adult MOET nucleus under different mating strategies and heritabilities. Journal of Animal Breeding and Genetics 108: 401-441.

- \& Măntysaari, E. 1992. Animal model evaluation in Finland: Experience with two algorithms. Journal of Dairy Science 75: 2017-2022.

Syväjärvi, J., Ojala, M. \& Hellman, T. 1983. Application of the direct sire comparison method to the Finnish dairy cattle population. Journal of the Scientific Agricultural Society in Finland 55: 525-539.

Tier, B. \& Graser, H.-U. 1994. Developing effective genetic evaluation system for beef cattle. Proceedings of the 5th World Congress on Genetics Applied to Livestock Production, 7-12 August 1994, Guelph, Canada Vol. 17: 173-179.

Uimari, P. \& Kennedy B.W. 1990. Mixed model methodology to estimate additive and dominance genetic values under complete dominance and inbreeding. Proceedings of the 6th World Congress on Genetics Applied to Livestock Production, 23-27 July 1990, Edinburgh, Scotland, Vol. XIII: 297-300.

- \& Măki-Tanila, A. 1992. Accuracy of genetic evaluations in dominance genetic models allowing for inbreeding. Journal of Animal Breeding and Genetics 109, 6: 401-407.

- \& Mäntysaari, E. 1995. Relationship between bull dam herd charasteristics and bias in estimated breeding value of bull. Agricultural Science in Finland 4: 463472.

Van Arendonk, J.A.M., Spelman, R.J., van der Waaij, E.H. 
Vol. 7 (1998): 207-217.

Bijma, P. \& Bovenhuis, H. 1998. Livestock breeding schemes: challenges and opportunities. Proceedings of the 6th World Congress On Genetics Applied To Livestock Production, 11-16 January 1998, Armidale, Australia, Vol. 25: 407-414.

Weller, J.I. 1994. Economic aspects of animal breeding. Chapman \& Hall, London. ISBN 0412597500. 244 p.

Wickham, B.W., Philipsson, J. \& Banos, G. 1996. Report of the INTERBULL sub-committee for 1994 and 1995.
Proceedings of the 30th Biennial Session of the International Committee for Animal Recording (ICAR): Performance recording of Animals, state of the art, 1996. Veldhoven, The Netherlands, 23-28 June 1996. EAAP Publication No 87: 93-101.

Woolliams, J.A. 1989. Modifications to MOET nucleus breeding schemes to improve rates of genetic progress and decrease rates of inbreeding in dairy cattle. Animal Production 49: 1-14.

\title{
SELOSTUS
}

\section{Perinnöllinen edistyminen suomalaisessa lypsykarjan jalostusohjelmassa}

\author{
Jarmo Juga ja Ulla Voutilainen \\ Kotieläinjalostuskeskus - FABA
}

Tämän kirjallisuuskatsauksen tavoitteena oli selvittää suomalaisen jalostustutkimuksen tärkeimpien tulosten vaikutusta suomalaiseen lypsykarjan jalostusohjelmaan ja tarkastella tiedon keruuseen, maiden sisäiseen sekä maiden väliseen jalostusarvojen laskentaan, taloudellisten painokertoimien laskentaan ja eläinten valintaan liittyviä mahdollisuuksia ja ongelmia. Lisäksi tavoitteena oli arvioida uudelleen suomalaisen lypsykarjan hedelmällisyyden, utareterveyden ja tuotanto-ominaisuuksien taloudelliset arvot ja perinnöllisen muutoksen taloudellinen merkitys suomalaisessa lypsykarjan jalostuksessa.

Utarehoitojen taloudellista arvoa määritettäessä otettiin huomioon 1) utaretulehduksen hinta mukaan lukien pois heitetty maito ja hoitokulut, 2) maidon hinnan aleneminen korkean solupitoisuuden vuoksi, 3) lisääntyvät lehmien uudistuskulut ja 4) karjan alen- tunut maitotuotos, mikä johtuu suuremmasta ensikoiden osuudesta. Korkea soluluku ilman näkyvää utaretulehdusta alentaa maidosta maksettavaa hintaa ja johtaa lopulta eläimen poistoon. Hedelmällisyyshoitojen kustannuksiksi sisällytettiin 1) hoitokulut, 2) lisääntyneet uudistuskustannukset ja 3) karjan alentunut tuotos. Tyhjäkauden kustannuksiksi laskettiin 1) ylimääräiset siemennyskulut, 2) lehmän alentunut vuosituotos ja 3 ) alentunut syntyvien vasikoiden lukumäärä.

Kotieläinjalostusinvestoinnilla on erittäin hyvä kustannus/hyöty -suhde, sillä yhden valintakierroksen taloudelliseksi arvoksi saatiin 876,9 mk lehmää kohden seuraamalla valittujen eläinten geenivirtaa seuraavien 25 vuoden ajalta ja diskonttaamalla taloudellinen arvo nykyhetkeen. 